\title{
Quality early childhood education for all and the Covid-19 crisis: A viewpoint
}

\author{
Jane Spiteri ${ }^{1}$
}

Accepted: 5 December 2020 / Published online: 5 January 2021

(C) UNESCO IBE 2021

\begin{abstract}
The purpose of this viewpoint is to consider the impact of the current Covid-19 crisis on the educational prospects of young children attending early childhood education and care (ECEC) settings. Studies show that health pandemics and environmental, political, and socio-economic crises jeopardize children's development and education. It is likely that for the immediate future, young children will continue to experience emotional and psychological stress. A curriculum that does not take into consideration a pandemic of the scale we are witnessing today creates unnecessary pressure and anxiety not just on young children but also on the adults who care for and teach them. This article outlines actions to ensure quality education for all as suggested by the United Nations Sustainable Development Goals. The response of ECEC curricula to the pandemic may potentially act as a catalyst for educational change.
\end{abstract}

Keywords early childhood education · curriculum · Covid-19 - pandemic · SDGs · quality education

Throughout history, humanity has experienced crises whose consequences have jeopardized children's development and education. Such crises include the 1918-1919 influenza pandemic, the Great Depression of the 1930s, and the 9/11 terrorist attacks of 2001, among others. Large-scale research on health, educational, economic, and socio-political disruptions has confirmed the immediate and long-lasting consequences of such crises for children (Benner and Mistry 2020). Studies that emerged following the 2008 Great Recession showed that children experienced more social and health-related inequalities, were at increased risk of maltreatment (Rajmil et al. 2014), and experienced more behavioral problems than previously (Golberstein et al. 2019; Kalil 2013; Motti-Stefanidi and Asendorpf

Jane Spiteri

jane.spiteri@um.edu.mt

1 Department of Early Childhood and Primary Education, Faculty of Education, University of Malta, Room 234, Old Humanities Building, Msida, MSD 2080, Malta 
2017). In a longitudinal study spanning the Great Recession, between 1998 and 2010, Wolf, Magnuson, and Kimbro (2017) reported that the proportion of kindergarten children living in moderate and high-poverty neighborhoods increased and the academic skills gap between poor and non-poor children within neighborhood poverty categories grew. The result was that these children started school less ready to learn than their peers in terms of their academic skills. Moreover, evidence from prior pandemics such as during the severe acute respiratory syndrome (SARS), in 2003, and the H1N1influenza virus, in 2009, suggests that children who suffered through these crises were less well-adjusted and experienced more pandemic-related stress (Ko et al. 2006; Main et al. 2011).

In these unprecedented times, when the global environmental crisis and the Covid-19 pandemic threaten the existence of humanity itself, young children are suffering dire consequences. The scale of Covid-19 has shaken all aspects of young children's lives, disrupting their education and their psychological, physical, social, emotional, and cognitive development and presents a significant and long-lasting risk to their health and well-being (Benner and Mistry 2020; Gromada et al. 2020).

Governments around the world have taken various measures to control the spread of the highly infectious coronavirus. One measure has been the closure of schools, even though emerging scientific evidence indicates that young children are less likely to pick up the virus and become seriously ill (Bond et al. 2020; Public Health England 2020). Yet, recent studies show that infected children who have no symptoms could be capable of spreading the infection (Harvard Health Publishing 2020). Indeed, there is strong evidence to suggest that while social-distancing measures may be effective in curbing the rise in new infections, they have led to increased anxiety and depression in children (Gromada et al. 2020), many of whom have been experiencing PTSD symptoms (Xie et al. 2020). Self- or government-imposed social distancing measures have also created more negative educational outcomes (Buzzi et al. 2020) and contributed to greater stress for both children and parents (Araújo et al. 2020). Other studies show that child maltreatment (Katz and Fallon 2020) during the pandemic has led to an increase in the number of child-abuse injuries (Caron et al. 2020; Kovler et al. 2020).

At the time of writing, 1.6 billion learners worldwide have been affected by school closures (UNICEF 2020). Given these figures, unless action is taken to minimize the impact of the pandemic on the education of young children, dropout rates everywhere are likely to increase in the future, with massive long term implications for the most vulnerable. The literature is clear on the negative effects a global crisis can have on young children's development and education. For this reason, a priority challenge must be to develop prevention strategies that enable quality education for all young children over the short and long term.

\section{Implications for young children in ECEC contexts}

The early years of a person's life are the foundation on which the rest of life is built (UNESCO 2020a). Good quality early childhood education and care (ECEC), or the education of children from birth till eight years of age (UNESCO 2020a), is known to have numerous benefits for the individual and society (UNESCO 2017), which the recent United Nations 2030 Agenda for Sustainable Development (United Nations 2015) has also recognized. In 2015, all UN member states adopted this 15-year plan to achieve 17 Sustainable Development Goals (SDGs) and 169 targets by providing a globally shared vision of sustainable development for all life systems on Earth (United Nations 
2020b). Of interest to the current study is SDG 4, which deals with quality education for all, and its Target 4.7, which recognizes ECEC as important for both children's personal development and achieving a sustainable future (UNESCO 2017).

Medical research suggests that children may be less susceptible to Covid-19 than adults (Bond et al. 2020; Public Health England 2020). Nevertheless, as a result of the pandemic, children are still at significant developmental risk due to disruptions to their proximal contexts. One major risk factor is the closure of schools (Gromada et al. 2020). Many children compelled to stay home have had their education prospects come to a grinding halt, while parents have faced the challenge of taking on teaching duties for the first time in their lives. The lockdowns have had negative consequences for the mental and physical health of children and adults alike (Gromada et al. 2020; UNESCO 2020b). Another risk factor is family disruption due to unemployment and financial instability, illness, death of family members, and the stress of the pandemic itself (Gromada et al. 2020; Araújo et al. 2020). Parents teaching their children at home must also cope with children's behavioral issues, which become more prominent during hard times.

Following school closure, many countries have been able to mobilize teaching online and employ innovative approaches to teaching and learning. The use of remote teaching platforms has increased exponentially during the current pandemic (Schleicher 2019; United Nations 2020a). However, studying at home affects children differently depending on their age. It is likely that the transition to online learning will negatively impact young children attending ECEC contexts since early years education is aimed at providing real-life sensory experiences, hands-on activities, and meaningful face-to-face interactions, which are hard to achieve virtually. Indeed, online learning can be ineffective and stressful for young children (Bond et al. 2020; OMEP 2020). While most research on children's use of technology for learning has focused on indoor learning, studies suggest many benefits from the use of technology as part of outdoor learning activities, such as the use of open-ended tablet applications, photos and videos, to support outdoor play and learning (McGlynn-Stewart et al. 2020). If put to proper use in conjunction with outdoor activities, more efficient online education platforms could meet the needs of many children.

Although the ripple effects of Covid-19 are still difficult to assess and model, its impact on the socio-economic status of nations is going to be a reality for many years to come. This is particularly so for children from low socio-economic backgrounds. Research shows that children living in low/middle-income countries are more vulnerable and least prepared for a health and educational crisis of this magnitude (Benner and Mistry 2020; Rajmil et al. 2014; Wolf et al. 2017). In addition, evidence strongly suggests that, while all children need support during a crisis (Gromada et al. 2020), those living in high-poverty neighborhoods need additional support (Wolf et al. 2017). Where there is a lack of resources and fewer opportunities for parental support, learning from home may accentuate the differences in children's educational progress, causing further inequality. In school, children can interact with peers and caring adults, opportunities that might not be available to young children whose parents face pre-existing health conditions or economic hardships, often made worse by the pandemic's psychological, emotional, and health impacts. The result is that Covid-19 is widening existing attainment gaps; it is not only a health crisis but also an education crisis (UNESCO 2020b). Maintaining motivation during these unprecedented times is difficult for everyone but especially for young children, who are likely to suffer the consequences for longer. To say that the Covid-19 pandemic has changed the course of ECEC dramatically is an understatement. 


\section{Final reflection and implications for practice}

While it is hoped that the negative impacts of Covid-19 will be short-lived, it is too early to anticipate when education systems around the world will resume their regular activities. Authorities seem more focused on minimizing the negative economic impacts of the spread of the virus than they are on the implementation of effective ECEC curricula. As a result, many countries have temporarily suspended the initiative to implement effective ECEC programs meant to ensure a sustainable world by 2030. With the disruption of the education trajectory of so many children, many of whom do not have support at home, huge global efforts are needed within the next decade to ensure successful implementation of the 2030 Agenda (UNESCO 2017). It is important that the UN critically consider the limitations that have slowed down its implementation in many ECEC contexts and to take further action to accelerate its success.

On the upside, UNESCO (2020b) argues that the pandemic is an opportunity to rethink curricula as well as teaching, learning, and assessment processes. This can only be achieved if nations are able to recover from the devastating effect of Covid-19 by making the appropriate adjustments to their respective national education plans. Governments, policymakers, and educators need to understand that the early years are a critical developmental period, a building block on which social learning, emotional well-being, and academic achievement occur over time. By rethinking curricula, by moving away from the one-size-fits-all approach to teaching and learning toward more individualized approaches, educators can increase their chances of successfully supporting young children's social outcomes. If we encourage educators and policymakers to move away from the idea of children as "becomings" toward a view of children as human beings (Uprichard 2008, p. 303), living here and now, the pandemic could bring about the much-needed change in curricula and pedagogies in the early years.

Although the initial versions of education at home during the pandemic looked a lot like the traditional teacher-led pedagogy, with many countries now reopening and taking learning outside the classroom, there is a ray of hope that ECEC will embrace more childinitiated learning and that Covid-19 will bring about a change from business-as-usual in the early years' learning environments, offering young children opportunities to explore and learn in nature with peers while encouraging meaningful, relevant, effective, and quality education for all. More importantly, Covid-19 could be the driver of change toward more creative, innovative, and flexible ECEC curricula. Such a scenario demands innovative solutions to reshape ECEC. As a starting point, this includes commitments from governments, educators, and policymakers to make deliberate efforts to create learning environments and opportunities that trigger young children's engagement and curiosity in meaningful ways.

The uncertainty brought about by the Covid-19 pandemic creates fear, and chronic fear is a precursor to toxic stress. Based on the proliferation of findings indicating the impact an economic or health crisis can have on young children's lives, it is likely these children will continue to experience emotional stress for the immediate future. It is time that governments, policymakers, and educators understand that holding on to a curriculum that does not take into account the scale of the current crisis creates unnecessary anxiety and pressures for young children. ECEC educators need to be mindful that the social and emotional needs of these young people may be qualitatively different as a result of the trauma experienced during the Covid-19 pandemic. As part of rethinking ECEC curricula, care for their emotional well-being must be taken into consideration. Children do well when they feel 
well. Caring educators who are attuned to children's emotional well-being will help them bounce back more quickly from the trauma the pandemic has caused.

The UN has indeed devotedly committed tremendous resources to achieve the education targets of the 2030 Agenda (UNESCO 2017) in ECEC, with some progress. Nevertheless, much more action is required to make the world a better place and to encourage creative and innovative learning activities in the early years. It may take some countries and individuals a long time to adjust to the opportunities this crisis-and new ones in the future- present. For their actions to be effective and inclusive, it is therefore critical to put in place appropriate ECEC teacher training programs and the necessary infrastructure and tools (UNESCO 2020b). While teacher training programs are generally well-positioned to address many educational issues, the current situation calls for more research into how the pathway of teacher preparation can contribute to professional learning, meet the needs of children in times of global crises, and strengthen the resilience of education systems so they can mitigate the damage the closure of schools has caused to young children's development and learning.

\section{References}

Araújo, L. A., Veloso, C. F., Souza, M. C., Azevedo, J. M., \& Tarro, G. (2020). The potential impact of the Covid-19 pandemic on child growth and development: A systematic review. Jornal de Pediatr (Rio J). https://doi.org/10.1016/j.jped.2020.08.008.

Benner, A. D., \& Mistry, R. S. (2020). Child development during the Covid-19 pandemic through a life course theory lens. Child Development Perspectives. https://doi.org/10.1111/cdep.12387.

Bond, E. C., Dibner, K., \& Schweingruber, H. (Eds.) (2020). Reopening K-12 schools during the Covid-19 pandemic: Prioritizing health, equity, and communities. Washington, DC: The National Academies Press.

Buzzi, C., Tucci, M., Ciprandi, R., Brambilla, I., Caimmi, S., Ciprandi, G., et al. (2020). The psycho-social effects of Covid-19 on Italian adolescents' attitudes and behaviors. Italian Journal of Pediatrics, 46, 1-7. https://doi.org/10.1186/s13052-020-00833-4.

Caron, F., Plancq, M. C., Tourneux, P., Gouron, R., \& Klein, C. (2020). Was child abuse underdetected during the Covid-19 lockdown? Letter to the editor. Archives de Pédiatrie, 27, 399-401.

Golberstein, E., Gonzales, G., \& Meara, E. (2019). How do economic downturns affect the mental health of children? Evidence from the National Health Interview Survey. Health Economics, 28, 955-970. https ://doi.org/10.1002/hec.3885.

Gromada, A., Rees, G., \& Chzhen, Y. (2020). Worlds of influence: Understanding what shapes child wellbeing in rich countries. Innocenti Report Card 16. Florence: UNICEF Office of Research - Innocenti.

Harvard Health Publishing (2020). Coronavirus outbreak and kids. Cambridge, MA: Harvard University. https://www.health.harvard.edu/diseases-and-conditions/coronavirus-outbreak-and-kids.

Kalil, A. (2013). Effects of the great recession on child development. The Annals of the American Academy of Political and Social Science, 650, 232-250. https://doi.org/10.1177/0002716213500453.

Katz, C., \& Fallon, B. (2020). Protecting children from maltreatment during Covid-19. Child Abuse \& Neglect. https://doi.org/10.1016/j.chiabu.2020.104753.

Ko, C. H., Yen, C. F., Yen, J. Y., \& Yang, M. J. (2006). Psychosocial impact among the public of the severe acute respiratory syndrome epidemic in Taiwan. Psychiatry and Clinical Neurosciences, 60, 397-403. https://doi.org/10.1111/j.1440-1819.2006.01522.x.

Kovler, M. L., Ziegfeld, S., Ryan, L. M., Goldstein, M. A., Gardner, R., Garcia, A. V., et al. (2020). Increased proportion of physical child abuse injuries at a level I pediatric trauma center during the Covid-19 pandemic. Child Abuse \& Neglect. https://doi.org/10.1016/j.chiabu.2020.104756.

Main, A., Zhou, Q., Ma, Y., Luecken, L. J., \& Liu, X. (2011). Relations of SARS-related stressors and coping to Chinese college students' psychological adjustment during the 2003 Beijing SARS epidemic. Journal of Counseling Psychology, 58, 410-423. https://doi.org/10.1037/a0023632.

McGlynn-Stewart, M., Maguire, N., \& Mogyorodi, E. (2020). Taking it outside: Engaging in active, creative, outdoor play with digital technology. Canadian Journal of Environmental Education, 23(2), $31-45$. 
Motti-Stefanidi, F., \& Asendorpf, J. B. (2017). Adaptation during a great economic recession: A cohort study of Greek and immigrant youth. Child Development, 88, 1139-1155. https://doi.org/10.1111/ cdev.12878.

OMEP [World Organisation for Early Childhood Education] (2020). OMEP position paper: Early childhood education and care in the time of Covid-19. International Journal of Early Childhood, 52(1), 1-10. https://link.springer.com/article/10.1007/s13158-020-00273-5.

Public Health England (2020). Coronavirus (Covid-19) in the UK. https://coronavirus.data.gov.uk/? $\mathrm{ga}=2.75843350 .200658073 .1590091913-1987132820.1581620573$.

Rajmil, L., Fernandez de Sanmamed, M. J., Choonara, I., Faresjo, T., Hjern, A., Kozyrskyj, A. L., et al. (2014). Impact of the 2008 economic and financial crisis on child health: A systematic review. International Journal of Environmental Research and Public Health., 11, 6528-6546.

Schleicher, A. (2019). Helping our youngest to learn and grow: Policies for early learning. International summit on the teaching profession. Paris: OECD. https://rb.gy/sctlui.

UNESCO (2017). Sustainable development goals: Learning objectives. Paris: UNESCO. https://unesd oc.unesco.org/ark:/48223/pf0000247444?utm_sq=gj34xbfn94.

UNESCO (2020a). Early childhood care and education. Paris: UNESCO. https://en.unesco.org/themes/ early-childhood-care-and-education.

UNESCO (2020b). UNESCO Covid-19 Education response: Education sector issue notes. Paris: UNESCO. https://en.unesco.org/covid19/educationresponse/issuenotes.

UNICEF (2020). Keeping the world's children learning through Covid-19. New York, NY: UNICEF. https ://www.unicef.org/coronavirus/keeping-worlds-children-learningthrough-covid-19.

United Nations (2015). Transforming our world: The 2030 agenda for sustainable development. New York, NY: United Nations. https://sustainabledevelopment.un.org/post2015/transformingourworld.

United Nations (2020a). Policy brief: Education during Covid-19 and beyond. New York, NY: United Nations. https://rb.gy/ufxv4m.

United Nations (2020b). The sustainable development agenda. New York, NY: United Nations. https:// www.un.org/sustainabledevelopment/development-agenda/.

Uprichard, E. (2008). Children as "being and becomings": Children, childhood and temporality. Children and Society, 22, 303-313.

Wolf, S., Magnuson, K. A., \& Kimbro, R. T. (2017). Family poverty and neighborhood poverty: Links with children's school readiness before and after the Great Recession. Child and Youth Services Review, 79, 368-384.

Xie, X., Xue, Q., Zhou, Y., Zhu, K., Liu, Q., Zhang, J., et al. (2020). Mental health status among children in home confinement during the coronavirus disease 2019 outbreak in Hubei Province. China: JAMA Pediatrics. https://doi.org/10.1001/jamapediatrics.2020.1619.

Publisher's Note Springer Nature remains neutral with regard to jurisdictional claims in published maps and institutional affiliations.

Jane Spiteri holds a PhD in early childhood education for sustainability from the University of Edinburgh. She is a full-time lecturer at the Department of Early Childhood and Primary Education within the Faculty of Education at the University of Malta. Her work focuses on early childhood education for sustainability and gifted education. 